\title{
Which are the duties and the limits of nursing in neonatal ventilation?
}

\author{
Salvatore Muscolo \\ From XXI Congress of the Italian Society of Neonatology \\ Palermo, Italy. 24-26 September 2015
}

It's difficult to talk about nurse's autonomy in ventilation assistance, because is a medical prescription. However in accordance with the Code of ethics, the professional profile and law 42/99, nurses have decision and operative autonomy in nursing care, which is achieved through specific autonomous and complementary interventions of intellectual, technical-scientific, managerial, relational and educational nature [1-3]. The treatment of respiratory meets the need: help optimize gas exchange, reduce breathing exertion and promote healing process reducing hemodynamic interferences. These goals can be reached individualizing the treatment according to the pathophysiological features of the disease and the time evolution of single pathology.

Monitoring peripheral oxygen saturation is more suitable method in the ventilated preterm ( $<27$ weeks) because transcutaneous oxygenation monitoring is not of routine use for lack of an adequate correlation with the blood gas and for highly sensitive skin.

Many studies suggest the prevention of lung damage and retinopathy of preterm concerning a prolonged hyperoxia by setting alarm limits in the event of administration of an oxygen concentration higher than $21 \%$. Numerous clinical conditions, including the need for mechanical ventilation, can affect and change the brain oxygenation. The near-infrared ray spectrophotometry (NIRS) is a technique that allows non-invasive monitoring of oxygenation and cerebral hemodynamics. It provides a single quantitative parameter $\mathrm{rSO} 2$ (regional saturation of oxygen) as an index of tissue oxygenation [4].

Compared to the intubated newborn there is not a unique method and standardized anchorage of the endotracheal tube. The quality of the attachment can vary

Correspondence: sal.musc@libero.it

Pediatric nurse, Neonatology and neonatal intensive care, Fondazione Ca' Granda, Ospedale Maggiore Policlinico IRCCS Milano, Italy greatly depending on the choice of the tape and according to the method of taping adopted.

No recommendation exists in the literature about the method of taping: the most widely used systems include the use of one or two strips cut to $\mathrm{Y}$ or $\mathrm{H}$. The adhesive tape, indisputably considered the system capable of guaranteeing the best results in terms of sealing, when applied with a taping system and encoded together with a hydrocolloid protective largely reduces the risk of injury [5-8].

The aspiration of the airways in infants should be based on careful clinical assessment and not on a routine basis. It recommended to avoid suctioning the nose but use saline drops instead, then suction the oropharynx [9].

Care posture is crucial because it promotes the stabilization of the neonatal functions and prevents bad posture [10].

It is recommended the use of ventilation systems with manual pressure control and delivered volumes in order to safeguard the delicate lung tissue.

\section{Published: 24 September 2015}

\section{References}

1. 1. Codice deontologico IPASVI â€ $€^{\mathrm{TM} 9}$ capo I art.2.

2. Legge 26 Febbraio 1999, n 42.

3. D.M. 17 Gennaio 1997, n.70.

4. Mosca F, Fumagalli M, Bray M, Barbarini M, Gagliardi L, Colnaghi M, Pugni L: Cerebral oxygenation and near-infrared rays spectrophotometry. Acta Biomed Ateneo Parmense 2000, 71(Suppl 1):599-607.

5. Beringer R. M.: Fixing reinforced tracheal tubes...a surprisingly complex problem. Anaesthesia 2008, 63:1139-1153.

6. Sadowski $R$, Dechert RE, Bandy $K P$, et al: Continuous quality improvement: reducing unplanned extubations in a pediatric intensive care unit. Pediatrics 2004, 114:628-632.

7. Grammatikopoulos T, Devane S, Hannam S, Greenough: A Method of endotracheal tube fixation and iatrogenic ear deformities. Eur J Pediatr 2003, 162(1):41-43.

8. Pavlichko M S, Seisler J, Yu M, Gambler S, Sorrentino D: Reducing Unplanned Extubations With Consistency And Collaboration. Reading 
Hospital and Medical Center, West Reading, PA Respiratory in Care Open Forum di New Orleans; 2012

9. Manuale di Rianimazione neonatale: American Heart Association, American Academy of pediatrics.

10. Smith AP, Saiki T, Hannam S, Rafferty GF, Greenough A: The effects of sleeping position on ventilatory responses to carbon dioxide in premature infants. Thorax 2010, 65(9):824-828.

doi:10.1186/1824-7288-41-S1-A25

Cite this article as: Muscolo: Which are the duties and the limits of nursing in neonatal ventilation? Italian Journal of Pediatrics 2015 41(Suppl 1):A25.

Submit your next manuscript to BioMed Central and take full advantage of:

- Convenient online submission

- Thorough peer review

- No space constraints or color figure charges

- Immediate publication on acceptance

- Inclusion in PubMed, CAS, Scopus and Google Scholar

- Research which is freely available for redistribution

Submit your manuscript at www.biomedcentral.com/submit 